\title{
The Pursuit of Happiness in the French Novel of the 20th-21st Centuries
}

\author{
Ruth Amar \\ University of Haifa, Haifa, Israel
}

\begin{abstract}
Happiness, as much a poetic as a philosophical, sociological, and psychological concept, has been, through the ages, at the heart of the needs each individual seeks to fulfil. But today, in a world dominated by technology, driven by productivity and dictated by efficiency, what about Happiness? Does it feature in works of fiction in any significant way? May it not have adopted different guises? Is that "duty of happiness" that Pascal Bruckner was talking about present in the French novel of the 20th-21th centuries? And if it is, has its force strengthened or weakened? This article will discuss the French Novels (of the 20th-21th centuries) that are devoted to or associated with Happiness in a direct or indirect manner. It will contextualize and analyze the transformation of Happiness, within the context of the historical and social events that influenced that period: the Holocaust, consumerism, postmodernism, structural social changes, the various as yet unarticulated new modes of life they created, and so on. To that end, this article will explore the discursive philosophical concept of happiness and its influence on the formation of the French novel. In so doing it will focus on the explicit discourse behind the motifs, the choices made in the process of writing, and the attitudes taken, considering the theme of happiness. Doing so, a significant discussion will be included regarding the paths of happiness, its agents, and the nature of the motifs and metaphors linked to the theme of happiness. The author will also address the dialectical role of the happiness theme in the constitution of an emerging literary discourse reflected in the French novel. By exploring the manifestation of the dogmas, ideas of the intellectual leaders of the 20th century (e.g., Jean-Paul Sartre, Simone De Beauvoir, Albert Camus) as well as the ones of the 21th century (e.g., Pascal Bruckner, André Comte-Sponville, Gilles Lipovetsky) new insights concerning the hybrid nature of the supposedly "authentic happiness" will be revealed. The author intend to inspect the theme of Happiness around four dialectical axes as a relevant ethical basis for delimiting the various fields of research: (1) Love, passion, and conjugality; (2) Ageing; (3) "The experience of everydayness"; and (4) "The era of emptiness". Focusing on the narratives, the article takes into account their specificity in the four distinct fields, all connected to existential and ethical issues. Finally, this article will attempt to analyse the assumed role of literature as a conduit of cultural awareness.
\end{abstract}

Keywords: French novel, Happiness, love, conjugality, morality, ageing, everyday life, postmodernism, emptiness, passion

What is Happiness? Happiness being at the centre of the human existence, is hard to define. Great philosophers, religious leaders, writers and thinkers throughout human history have asked themselves this basic question. Regarding the etymology of the word "happiness", in the Historical Dictionary of the French

Ruth Amar, Lecturer, Department of Comparative Literature, University of Haifa. 
language the term comes from the Latin word "augurium" which is translated as "omen" favourable or not, that means good or bad "luck" - but only the sense of "good luck" was kept. Following a shift in meaning, the term has transformed into the value of "fate, condition, destiny". It is this meaning that appears in the old French term "fate, luck", derived from "EUR", augurium in Latin, meaning "increased granted by the gods".

Seeking happiness assumes paramount importance in human consciousness because it serves as a climax for the individual's existence. The Greek philosophy is concerned to a great extent with happiness where it is considered as the natural privilege of individuals having an equilibrium between desires and faculties (in Aristotle's doctrine, activity is one of the most important conditions to be happy). For Epictetus, happiness relates to an essential element: duration - thus true happiness is to last forever, and cannot be crossed by any obstacle. Anything lacking these two characteristics is not true happiness which should be distinguished from furtive moments of joy, contentment or satisfaction. According to Seneca the attainment of happiness is possible only by following Virtue and virtue consists at following Nature.

Although the concept of Happiness is extensively analyzed in philosophy, sociology, psychology, it has gained little attention in literary criticism, especially with regard to the twentieth century French novel. Why is the term happiness suspicious to the "Doxa" or to the general consensus of the novel? Most writers feel discomfort when it comes to express happiness in their novels, the belief being that writers deal with "dramas" and "calamities" of the world and humanity. For many writers a concrete story of happiness is inconceivable or at least the subject can be treated only obliquely. But for some writers it is not so. One can notice the theme of happiness in the French novel of the twentieth century through singular dramas where the presence of diverse stories of happiness draws our attention.

The first purpose of this article is to reveal the persisting interest in the writing of happiness or at least of its pursuit throughout the 20th-21st centuries, and the way it is expressed implicitly or indirectly in the various novels, taking into account its relation to social events, as well as historical and philosophical doctrines of that period. The second objective is to determine if happiness has gone underground, adopting different guises or waned in the contemporary period. Has it been replaced by another relevant force that emerges in the texts? In order to achieve these intentions the theme of happiness will be examined using an epistemological frame as well as an ethical dimension, and taking into consideration a chronological development.

\section{"To Be in Order to Do"- The Early 20th Century}

In the early twentieth century, an approach of happiness appears in the novels that consists in "being able to accomplish or to act". It seems that this position reflects the principles of The Conquest of Happiness by Bertrand Russell (1930). After removal of unattainable obsessions, the philosopher proposes a balanced life, made of thoughts and actions, a successful and diverse life where it is possible to acquire a harmonious personality. Russell is modern in the sense that he adheres to the Freudian theories which give the text a psychological dimension and an original balance: "My own belief is that a conscious thought can be planted into the unconscious if a sufficient amount of vigour and intensity is put into it" (Russell, 1930). For Russell, a coherent goal is accomplished above all, through activity and work. The book ends with an almost poetic and even metaphysical chapter, where Russell invites to knowledge as a means of detachment.

We find echoes of this principle in several novels and in particular those of André Gide and Jean Giono. Yet, another principle related to the concept of happiness is also noteworthy in their novels to be happy in order to make others happy. The interest in the writing of happiness persists throughout the twentieth century, with 
various ideas which in the twenties, are noticeable, all through an approach which may be described as "to be in order to do". Two authors have adopted this scheme: Andre Gide and Jean Giono. Fascinated by happiness they put in the heart of their lives and their work. Gide, influenced by Montaigne, Rousseau, and Stendhal, researched like them a form of authenticity based on lucidity. In the Nouvelles nourritures, he writes: "It seemed to me that the best and safest way to spread happiness around me was that I myself, had to reflect the image of happiness, and I was determined to be happy" (Gide, 1935, p. 220). For him, happiness is based on the development of our own being, which is accomplished from time to time by the destruction of the old "self". He adopted the motto of Goethe: "Die and become!" (Cespedes, Baritaud, \& Anglard, 1991, p. 3). However, Gide's will was to connect his individualistic ethic with the happiness of others:

There is on earth such an immense misery, distress, embarrassment and horror that the happy man cannot live without being ashamed of his happiness. And yet, he who does not know how to be happy can do nothing for the happiness of others. I feel within me the absolute obligation to be happy. But happiness obtained at the expense of others and by depriving them from possessions is hateful. My happiness is to increase that of others. I need the happiness of all to be happy myself. (Gide, 1935, p. 220)

For Jean Giono, who mostly follows Pascal's system of belief, happiness is based on the detachment of the inessential. The pursuit of happiness will thus be for him a quest where "each one as Angelo in The Horseman on the Roof, must climb the mountain to discover that happiness is not found in the possession of things but in detachment" (Cespedes, Baritaud, \& Anglard, 1991, p. 3). For these two prestigious authors of the early century, happiness is not "to possess", or "to give the impression", but simply to be happy yourself before you act for the happiness of others.

The work of Jean Giono reveals an obsession with happiness (echoed in two subsequent novels Que Ma joie demeure, Les Vraies richesses ${ }^{1}$ ) which persists throughout his writing career: the second volume of the cycle Le Hussard sur le toit is entitled Le Bonheur fou ${ }^{2}$. During the 1960s he wrote La Chasse au bonheur. His oeuvre is an ode to happiness, for joy in his lyrics is his true goal. On several occasions he expressed his hierarchy of values: "J'ai une façon un peu particulière d'exercer mon métier. Au lieu de l'argent, ou de la gloire, je cherche mon plaisir (I have a particularmanner to carry on my profession. Instead of money or glory, I look for pleasure)" (Cespedes, Baritaud, \& Anglard, 1991, p. 100). "Mon problème à moi, c'est la recherche du bonheur. De ma vie, je n'en ai connu d'autres" (My personal problem is the pursuit of happiness. In my life, I have never experienced any other problem $)^{3}$. In this perspective, Giono appears here forerunner of the positive philosophies, which invite to see life optimistically. Lately, Giono's philosophical approach has been enriched by essays promoting a new method: positive psychology. The right question is not "Am I happy?" but "how can I be happier than I am?" Happiness is seen more as a practice and a condition. The second main aspect is that happiness is apolitical and is often the product of very simple elements. The author's objective is the serene outlook on life: man can magnify the aspects of his ordinary life and create a happy life. As Rémy Pawin explains Giono's work contributed to the emergence of what became within seventy-eighties:

L'acculturation des populations à cette valeur devenue centrale dans les sociétés occidentales [...] Son discours sur la vie heureuse a donc témoigné, non pas des idées les plus prégnantes de l'époque, mais de "l'irrésistible ascension » du bonheur comme norme au sein de la société française (The acculturation of populations to the value that had become a

\footnotetext{
${ }^{1}$ Que ma joie demeure (Paris: Grasset, 1935); Les vraies richesses (Paris: Grasset, 1936).

2 Le bonheur fou (Paris: Gallimard, 1957).

3 Jean Giono, Carrefour, t. XV, n 713, 14 mai 1958.
} 
central issue in Western societies [...] His speech on happy life witnessed not only the most pervasively present ideas of the time, but also "the irresistible rise" of happiness as a norm within French society). (Pawin, 2011, pp. 19-32)

The notion of happiness considered by Gide and Giono underlines both the approximate nature of the links between life and writing and the flux of meaning that occurs in the ethical movement between them.

\section{The Existentialist Approach}

A significant philosophical thought which influences the novelists in the twentieth century is based on Nietzsche's doctrine of nihilism, rediscovered in the 19th century. This philosophy is based mainly on the fact that human existence is devoid of any meaning, any purpose, any comprehensible truth, or any value. According to Nietzsche, the normal condition of nihilism, which is the negation of being, is a final rejection of idealism and its consequences.

In the thirties, under the influence of nihilism another thought is developed: the existentialists put forward the idea that individuals create the meaning and the essence of their lives: "existence precedes essence", that is to say that we initially appear in the world, then exist and we finally are defined by our actions for which we are fully responsible.

From then on, considerable changes in the literary expression of happiness enrol in the forties. Among contributions that either incorporate or solicit a response to the question of happiness the works of Camus and Sartre are considerable. The latter states in Existentialism Is a Humanism: “...if existence truly does precede essence, man is responsible for what he is. Thus, the first effect of existentialism is to make every man conscious of what he is, and to make him solely responsible for what he is" (Sartre, 1946, p. 23).

Sartre highlights the increased anxiety that is already central in Malraux's work where commitment and obsession of meaning are reflected in the human condition from 1933 on. In his texts, the concept of happiness is in the logic of the collective good. The individual has obligations towards the community where the free and full development of personality is possible. Thus, it is obvious that man is fundamentally a social being. Moreover, the very notion of happiness is given by the community. In both The Wall and Nausea, Sartre brings to light a new pessimism, strengthened by the coming war.

The existence facing death becomes absurd; man hopelessly alienated from nature and at the same time from the others, becomes the prey of strangeness where it becomes difficult to find any notion of happiness. Nausea explores the cruel disintegration of the essential elements of Roquentin's happiness. But this narrative also exposes moments of joy that are possible only through the process of writing. In other words, behind the printed words does something exist that can overcome the feeling of existential misery.

For a creative writer like Camus who clearly feels an urge to do or to make things happen, happiness is essential. He explains in his diary: "There is no shame in preferring happiness". Diego, the hero of The State of siege (L'état de siege), claims: "I have to take care of my happiness". This assertion is reinforced by Rambert, In The Plague (La Peste), who declares: "There is no shame in being happy all alone". And we realize that personal happiness is not a disgrace for Camus as long as it is conceived as a way to help the others. In an interview, a few months before his death, he declares: “... I am rather inclined to believe that we must be strong and happy in order to help people in distress". In the same interview, he refuses to speak of his happiness as if it were a mistake. Somehow, this distinction is called into question as we see that in his work, the pursuit of happiness at any cost leads nevertheless to negative and tragic heroes. However, while they are in a hopeless situation where the possibility of happiness seems far away, they claim to be happy. Camus' work can be 
divided into three periods:

- The absurdity cycle: where man reaches happiness alone facing the world: solitude is then the condition of happiness;

- The revolt cycle: where Camus advocates solidarity; man leads a collective struggle against evil to be entitled to achieve happiness;

- The reconciliation cycle: where man finds a balance between the egotistical passion and the need of solidarity.

Betwixt and Between (L'Envers et l'endroit) and Wedding (Noces) show moments of happiness in which the author confirms his simple but profound harmony with the world. At this stage, the happy union of man with the world is not the subject of a quest anymore, but a simple statement that does not involve any action in reality. A Happy Death (La Mort heureuse) on the contrary, denies the world of poverty and becomes the story of Patrice Meursault's pursuit of happiness, strongly connected to his wish to obtain money-this finally leads him to kill Zagreus.

Caligula, another hero of Camu's work, has a strong need to change reality as he pleases: engaging in perversion and destruction of all values, he claims: "there are two kinds of happiness and I have chosen that of murderers. Because I am happy. ... in the end... it is a barren and beautiful happiness". The hero of The Fall (La chute), Batiste Clamence, for whom happiness seems no longer to exists, finally proclaims the possibility of finding it at the end of his confession. In The Stranger (L'étranger), Meursault thinks about his happiness in his cell when sentenced to death, while Sisyphus does the same in his hell as the essay concludes: "the struggle itself ... is enough to fill a man's heart. One must imagine Sisyphus happy”. Acknowledging the truth gives hope to Sisyphus who keeps pushing absurdly while knowing the futility of his task and the certainty of his fate, but he is free to realize the absurdity of his situation and to reach a state of contented acceptance.

Simone de Beauvoir, representative of her period, highlights the tensions crystallized around happiness; happiness is first in conflict with another value of Beauvoir's constellation: creation and literary posterity. According to Pawin (2011, pp. 19-32), Beauvoir appears here as a representative of a generation, that of Cioran in particular, for whom "suffering is to produce knowledge". That generation conceives happiness as a "lapse", a "sleep", an abdication, an inactivity which leads to resignation. Happiness is a gendered issue, which is often offered to women in compensation for their exclusion from public life, as expressed in Montherlant's The Girls $^{4}$ : social success and fame go to males; happiness in domestic life goes to women. For the ethical-political issue of fulfilment does not concern a woman's happiness. Happiness may be chosen or accepted in exchange for the deprivation of freedom. As the "Others", women are returned to the metaphysically privileged world of the child. Pawin explains that "they experience happiness from a point of view of not being responsible for themselves, of not having to make consequential choices". From this existential perspective women may be said to be complicitious in their subjugation. Beauvoir's existential charge of bad faith must be understood within her Marxist analysis of the social, economic, and cultural structures that frame women's lives. Though Beauvoir does not argue that these structures deprive women of their freedom, she does not ignore the situations that make the exercise of that freedom extremely difficult.

According to Pawin, in Beauvoir's texts, the conflict between happiness and social success appears as in Madame de Stael's work who claimed "Glory, is for a woman mourning happiness". This sentence,

${ }^{4}$ Henri de Montherlant, The Girls (Pan Books: 1987). 
paraphrased many times in Beauvoir's autobiography, will finally be refuted by her: "I will have a happy, fruitful, glorious life' I said to myself". Thus, for Beauvoir, happiness is gradually justified: it is not a transcendent purpose; it sometimes opposes creation; it is not politically legitimate. These tensions around Happiness are expressed in many discourses and represent the beliefs of the time (Pawin, 2013).

\section{Happiness and Conjugality in the Consumer Society}

After and despite the Second World War and Auschwitz, the pursuit of happiness is present, formulated in one way or another in the texts. The feeling of happiness is not absent from the then-novel, but it is rendered in the form of fragments and allusions coming up in the consciousness of a character or a present narrator. In the fifties the French people experience a kind of "consumerist happiness" but from the sixties, they began searching for "quality of life". Pawin notes that before 1945, "higher principles" were opposed to the pursuit of happiness. Only women, excluded from public life and politics, were able to locate happiness on top of their pyramid of values without creating a scandal.

Moreover, in a world marked by violent memories of two world wars and the tragedy of the Holocaust, we could by no means say that happiness was a central concern. It was not until the second part of the 20th Century that we witness an "irresistible rise of the value-happiness".

The interest for happiness persists in postmodernism where the whole mass culture is on trial. Thus, from the 60s, Jean Baudrillard (1983) denounces the "egalitarian ideology of well-being", the "democratization of television, the car, the stereo" (p. 60). He claims that happiness is not simply born from a natural impulse inherent to the individual, but rather comes from the fact that the socio-historical happiness is the new version of the equality concept that had developed during the French Revolution of 1789: "all the political and sociological virulence that this myth is responsible for since the Industrial Revolution and the revolutions of the nineteenth century were transferred to happiness". Along with this idea, Christiane Rochefort in her novels Les Stances à Sophie (Rochefort, 1978) and Une Rose pour Morrison (Rochefort, 1966) critics happiness as conceived by the bourgeois couple, namely, money and possession are the two elements that create happiness for the consumer society.

Married life, a subject of numerous controversies regarding access to happiness and frequently explored in the twentieth century, is also connected to this development. According to Jacques Chardonne happiness can be read as a kind of protection and an illustration strongly related to married life and love already in 1934. The mysterious power of love in marriage is the key to happiness, love as defined in Chardonne's Sentimental Destinies (Chardonne, 2000), is love "produced by a slow distillation, a precious essence of development where body and soul are fused ... for love to exist, there must first be a complete equality between man and woman, mutual respect, mutual understanding".

Fifty years later, marital happiness is still the subject of several novels like Pascal Bruckner's Bitter Moon (Bruckner, 2003) - but this time it is mainly to be put in derision. From the very title, a Freudian slip is ironically introduced the French word "Fiel" (meaning bitterness) instead of "Miel" (meaning honey), which suggests the failure of life together. Bruckner became famous in the seventies for his essay The new disorder in love (an analysis of the sexual revolution of the 1960s and 1970s) written in collaboration with Alain Finkielkraut. Since this publication, this novelist and philosopher continues to question and analyze with sarcasm the evolution of relationships in love, the couple, the Western desire. He demonstrated a rejection of utopias from May 68 and that of the consumerist vision of seduction relationships. 
In 2000, Pascal Bruckner publishes Perpetual Euphoria: On the Duty to be Happy (Bruckner, 2011) where he maintains that happiness has become a pervasive obsession "a kind of obligation" in European contemporary society. The ideology regarding the first half of the twentieth century grows to "evaluate everything in terms of pleasure and inconvenience, a duty to euphoria that rejects in shame or discomfort those who do not subscribe to it".

The question therefore is that of an obsession and not just that of an individual duty as it was the case in the text of Alain in 1925: On Happiness (Alain, 1973) where he states that happiness is a duty, "it is impossible that one be happy if one does not want to be; so one has to want his happiness in order to achieve it". Thus everyone makes the effort to achieve their own happiness according to their own needs while in this new era where everything is allowed, where every opportunity is offered to him, man has gone from the idea of happiness wished, to happiness as an obligation.

It seems that this is the first fault committed by Franz, the main character of Bitter Moon, who believes in the possibility to control happiness, while it would have been wiser for him to recognize happiness and know how to preserve it. Like a machine, Franz tolerates life only on the peaks; falling back onto earth is experienced as a profound failure. Constraining Rebecca his wife to follow him, making her fulfil his increasingly mad desires, Franz leads them both into a destructive circle.

In this frenzy of happiness, tired of his relationship with Rebecca, Franz never knows how to accept moments of boredom in marital life: he is afraid of banality, another term related to Bruckner in modern times.

The term of banality has also been used more recently and again in relation to married life in the work of Eric Holder. While starting in his texts with simple life without suspense in Mademoiselle Chambon (Holder, (2002), Holder puts marital life to the test of passion outside of marriage. The discovery of passionate love is the key to happiness for Antonio and Mademoiselle Chambon. The intensity of this happiness is strengthened by the freshness of this state and the two characters' increasing astonishment when discovering passion. However, in this case, if the temptation of destructive passion exists, it remains only in the limits of temptation. The tearing of the soul between the blindness of love, the imaginary projection of being happy and a bad conscience towards his wife Marie, prevent Antonio from carrying out his passion for Mademoiselle Chambon. He finally decides not to leave his family, and happiness remains inaccessible for the lovers. But in the end even though there is a disappointment of the passionate love failure, there is on the other hand, serenity and comfort in the banality of the friendly love he feels for his wife and family.

The Silk Thread (Gazier, 2001) is a fantastic story based on the myth of androgyny, a love story built on the same passion: haute couture. Between Odile, a great fashion dressmaker in Paris, and Odon, there are several disparities, including thirty years apart in age (Odile is older), but two aspects connect them forever: high fashion and love. However, the most important element of the story is that of identity: can a man become a woman to breathe life into his beloved? In the fantasy of their mad success they live as a solitary couple, seclusion becoming the delight of their soul and flesh, and when Odile dies, Odon gradually takes her place and steals her identity, so that finally "one no longer knows who they are: he or she". The epiphanic sensation of Happiness experienced with the two lovers now merged into one being, is done in secrecy and in concealment.

\section{The "Positive Minimalists" and the Everyday Life}

The term of banality is connected to other texts without being necessarily related to marital life. While most novelists dare address happiness in an indirect way, a group of writers called "positive minimalists" by 
Vincent Engel, write the everyday life, arguing that it can lead to happiness, a simple and intimate happiness. This everyday life described by Bruckner as "disgusting by its monotony", is praised by the "positive minimalists", arguing that it may lead to a simple and intimate happiness. This literature designated by Jacques Poirier as a literature of "presque rien" ("almost nothing") or "pas grand-chose"5 ("nothing much") hides a paradox, since it is far from writing "almost nothing"; in fact, it evokes the neutral mode of an essential reality: “il y a loin d'une écriture du 'presque rien' évoquant sur le mode du neutre une réalité essentielle, une écriture en miroir et une écriture en écart, qui toutes deux renvoient du monde une image en creux (Far away from being a writing of 'almost nothing' referring to the neutral mode of an essential reality, it is a reflecting writing and a writingat distance, that both send back from the world a hollow image)". 6

In these stories where nothing or not much happens, boredom and banality are present. It is a quiet and sometimes serene boredom, a positive and modest banality, a condition that requires nothing of us, or very little. So that this boredom is finally, by its absence of project, "freedom".

This group includes prominent writers are Christian Bobin, Colette Nys-Mazure, Pierre Bergounioux, Pierre Michon, Pierre Autin-Grenier, Francis Angle, Gil Jouanard and others. Almost at the same period, in 1999, André Comte-Sponville published Happiness Desperately (Comte-Sponville, 2003) where the main idea is that we should not live or hope to live better in the future, but that real wisdom is to live with pleasure and joy in the present, desiring what we have at the present. That's what he calls happiness in action, a happiness that hopes nothing. According to Comte-Sponville, it is the philosophy that can put us on the path of happiness, because its purpose is wisdom and it should not be obtained by tricks, illusions or entertainment in Pascal's sense of the term.

If we look more closely, the criteria underpinning the work of the positive minimalist writers originate from the doctrine of Comte-Sponville. It is based on a new way of living - and writing - expressing daily life, which we can identify in literature, in the course of the nineties. Without knowing each other, these authors almost simultaneously initiated a new writing style which, despite their independence, found themselves in a kind of common emotional response. Thus, each in their own way, these authors write about daily activity, while their writing continues to question the validity of a boundary between reality and fiction. The result of this process is an ethical bond between their works: even though they are different, they all engage in revealing how through the power of words, the authors deploy reality, revealing the intensity of each moment lived, and unveiling new meanings. In 1998, Bertrand Visage announced the "emergence of a literary movement" and labelled these writers as the "Less-than- nothing", writers who have questioned the constraints of the novel, where each "private happiness sip introduced a query on how people can live together" (Visage, 1998). Indeed we realize that the very detailed "nothing" on which these writers insist on the one hand, grows and spreads to the dimensions of the individual, and on the other hand, asstated by Pierre Assouline: "leurgoûtdulaconisme [...] neconfinejamaisàlasécheresse". Here the sentence is already translated before so I moved it now into parenthesis ("their taste of laconism [...] never confines to lack"). ${ }^{7}$

Gilles Deleuze in Proust et les signes, distinguishes two classes of writers: the "microscopic" ones and those of "longues étendues" ("long expanses"). The first slow down the rhythm of writing entering into detail,

\footnotetext{
${ }^{5}$ Jacques Poirier, Le roman français au tournant du $21^{e}$ siècle, Bruno Blankeman, Aline Mura-Brunel, Marc Dambre, Presse Sorbonne Nouvelle, 2004, pp. 371-380.

${ }^{6}$ Ibid. p. 371.

7 Pierre Assouline, «Les petits riens», Lire, Paris, Février 1998, p. 6 (262).
} 
minimal traces, while the latter as Proust, devote themselves to the joy of observing from afar the realities, difficult to capture closely. The minimalist-positive, you may have guessed, walk in the footsteps of the first group, granting themselves the pleasure of the tiny detail and sometimes even to the imperceptible facts.

The work of the positive minimalists also shows the influence of Michel de Certeau who draws our attention to the simplest elements of daily life. His book, Practice of Everyday Life, 1 / Arts to do, 'A very ordinary culture published in 1980, is addressed not only to the mind, but also to emotions, and how perceptions and actions are intertwined in life. De Certeau examines the way in which people individualize mass culture, using the manufactured products to adapt them to their everyday life. This development presents a new way of thinking, feeling, and experiencing the complexity of perception and human behaviour in various areas related to daily life. After the war, in a world of despair, the novels deal with the human need to recapture traditions, language, symbols, in everyday situations in order to reach happiness. All these daily activities are more or less present in the "positive minimalist" authors' texts. The search for a practical everyday wisdom is expressed in their work that reflects a need unveiled by Pierre Macherey who emphasizes the religious tendency of man. ${ }^{8}$

A major author of the positive minimalists group is Philippe Delerm, whose writing on the everyday life interrogates the fruitful relationship between reality and fiction. On the basis of happiness expressed in his books, the doctrines of Epicureanism and stoicism are reflected, the main idea being that man should wish what he already has. No desire for renewal. No lament of lack. Thus, in his texts he introduces themes such as childhood, feelings, impressionism, Folon's drawings, Normandy—all these elements are incorporated simply and effectively in short chapters, a kind of bubbles that are neither stories nor essays. By a choice of exact words, Delerm organizes reality, revealing the intensity of each moment lived but at the same time, he discovers new meanings. Ethics and aesthetics are implemented in order to better tell the everyday.

\section{Happiness and Old Age}

The consequences of old age have great influence on the development of the happiness theme in Literature. How can we expect to consider happiness in old age? Happiness of a body that is suddenly unfaithful? Happiness of the soul tarnished by all overwhelming memories, by mourning? Is it possible to design happiness when old, in a society obsessed with productivity, profitability?

In literature, the theme of old age is in the centre of several works. If we want to evoke the famous titles, we should evoke the tragedy of King Lear where Shakespeare presents the situation of a man who has reached the last stage before death. Shakespeare paints the main protagonist as a slave of ambition, jealousy and anger, which reach their peak in old age: King Lear asks: "Is man no more than this? Unaccommodated man is no more goal Such a poor, bare, forked animal of art thou? ...”. In order to portray his main hero Shakespeare uses the negative stereotypes of old age: the king is miserable, irritable, angry, lacking judgment and evaluation capacity, and he finally loses his sanity. His audacious and intrepid decisions have nothing to do with reality (Lear is blind regarding his own daughters and stubborn and cruel towards the one who tells him the truth). Through Lear Shakespeare exposes other deficiencies like idiocy, weakness, attributing them to natural aging. The king does not learn anything from this lesson on the human species; instead of admitting his mistakes and becoming responsible for his actions, he remains fickle and superficial.

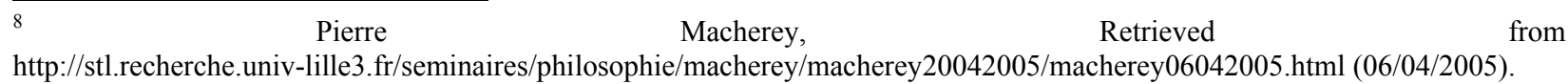


Molière plays reveal elderly characters who arouse but contempt and repugnance. Molière's old men are crafty, suspicious, stupid, greedy, and ridiculous, and above all, they are never aware of their despicable behaviour. The playwright is severe with old age which he considers the most odious stage of existence, leaving no room for the positive. For instance, in L'Avare, Harpagon (from Latin harpagonem: gripper, thief) is devoured by greed and plagued by maladive senility - two characteristics related to old age.

Complying with the presentation of Molière's old men, in the 19th century, Balzac's novels Eugénie Grandet (1834) and le Père Goriot (1835) illustrate the negative stereotypes of old age: greed, poverty, bitterness, dependence. Balzac's old characters are passionate for a subject or a particular object: Père Grandet, known for his extreme avarice despite his considerable wealth, deprives his family, and requires all the conditions of poor life to preserve his fortune (the only supreme value for him), while Père Goriot's obsessive passion is directed to his daughters on whom his happiness depends entirely. Exploited and finally abandoned by his daughters, he dies in solitude.

At the turn of the 20th century the question of old age is raised by André Gide. In Les Faux-monnayeurs (1925), the writer wonders why literature speaks so little of the elderly. He explains this discriminatory attitude assuming that young writers are not concerned with the problems of old age, while older writers prefer to draw the portraits of young protagonists, as an old man faced with death is no longer suitable to be a hero: nothing important will happen to him. As he explains: "un vieil homme n'intéresse personne... (an old man is just of no interest whatsoever)".

From the fifties, a mutation occurs on the account of old age, notably with The Old Man and the Sea (1952) by Ernest Hemingway. In this story, unlike the others, the old man is fruitful and creative, and his portrait is created out of various virtues. In drawing this portrait, and using maritime metaphors and a symbolic giant fish, Hemingway shows the triumph of man over the obstacles of life. Indeed, this book seeks to convey the idea that it is at an advanced age that man gains strength and human wisdom, that it is this period that conveys the sum of knowledge and experience accumulated during a lifetime.

During the 20th century we witness a powerful and increasing tendency of the Western literature to deal deliberately with aging. Writers no longer content of its representation or use of stereotypes in their works, expand the debate on old age itself, and seek to understand its significance for the individual and its relations with society.

Therefore, projects, activities, ways of being, of looking at life, at old age, at death, are referred to the individual's responsibility. As Simone de Beauvoir explains in La Vieillesse: "la société de consommation [...] a substitué à la conscience malheureuse une conscience heureuse et réprouve tout sentiment de culpabilité (Consumer society [...] substituted a happy conscience for the unhappy consciousness and at the same time, rejected any feeling of guilt)". ${ }^{9}$ The outlines of new areas of involvement are emerging. "Aging well" or "Vital ageing" is now the task of the individual.

In this vein, L'Angoisse du roi Salomon, one of Romain Gary's last books (1979), is entirely devoted to the various aspects of aging and old age. At first sight, it seems that the story is about the sorrow of old age, the fear of imminent death. It turns out that the anxiety and pain described by the young narrator are not necessarily the emotions felt by elderly people that surround him, but the ones he affiliates erroneously to the elderly. He believes that in old age no dreaming of love or sexual relationships are plausible. The young narrator embodies

${ }^{9}$ Simone de Beauvoir, La Vieillesse, Paris, Gallimard, 1970, p. 8. 
all the prejudices of old age. However, old Solomon's behaviour contradicts these stereotypes: he has high morale, a strong temperament, he is stubborn, easily annoyed and feels a strong desire to live and communicate.

We can observe a fundamental shift from the design of old age in the novel of the second half of the 20th century, when recognition of ageing in man's existence is not just a last step before death. At the beginning of the third millennium, contemporary society is characterized by an increase of life expectancy and it appears that literature takes into account the new possibilities offered by medicine and technology. All these social phenomena contribute to the emergence of unprecedented attitudes toward old age and the prospect of death which are strongly reflected in the novels considered.

The design of old age in the French contemporary novels reflects the pleasures of ageing, or at least it reveals that old men and women are aware of the fact they have lived a more or less serene life before reaching the final stage of existence. These stories depict octogenarian characters who, knowing how to restrict their passions, adapt to their new life with limited capacity.

Noces de Chênes (2008) by Régine Detambel where old age, far from being an epilogue or the end of the vital impulse, is an age of renaissance, both in terms of the regeneration of sensations and in terms of erotic and fruitful invention. According to Martine Boyer-Weinmann in Noces de Chênes, "La vieillesse vue par Detambel est aussi un moment chrysalidaire et un concentré violent de tous les âges antérieurs (du stade prélangagier, antémnésique, au stade de la perte du langage et de la mémoire en passant par l'hypermnésie)... (The old age as seen by Detambel is also a transitional moment and a violent concentrate of all previous ages [from the stage before language to the stage of the loss of language and memory through hypermnesia])" (Boyer-Weinmann, 2011, p. 175). The octogenarian Taine is miraculously saved from decay by old Vitalie who collects him in her home and heals him. But instead of enjoying this new happiness Taine escapes. As Boyer puts it, it is "signe d'accès à une nouvelle identité et indépendance, en l'espèce celle de rompre une nouvelle fois l'attachement aliénant par la fugue et l'aimantation d'une figure d'amour supérieure (a sign of achieving a new identity and independence, which in this case is the break of commitment, alienating by evading and magnetization of a higher figure of love)" (Boyer-Weinmann, 2011, p. 175). Taine chooses to leave the shelter that he was offered by his companion to gain better, to continue his solitary walk as he has finally realized it will make him more alive and happier. What seems to interest Detambel is the way an old individual thinks and arises from his weakness condition to manage to take action and evolve.

Marie Rouanet, in La Marche lente des glaciers, expresses the idea that aging is a readiness to condensation and attention to an inner world while La Dernière Leçon by Noëlle Châtelet explores the feelings elicited by the programmed suicide of the author's mother, a ninety-two years strong old lady who confirms the serenity of her "fulfilled life".

Bluebird published in 1999 by Michèle Gazier is an implicit reflection on happiness in old age showing the author's predilection for happiness contiguous with non-compliance: the sudden happiness surprises an octogenarian couple before death. The novel deals with the complicity between an octogenarian couple (the husband is an ornithologist) and a young North African, Alain who apparently have nothing in common. This bond leads to a vision of happiness essentially beyond the usual social conceptions and transgresses what should be in line with the local social norms of a little French village. Gazier draws a parallel between a Bluebird and Alain, the main hero: both symbolically merge and carry the key to happiness. Conducting a scientific research on the Bluebird, the couple is actually in pursuit of happiness that remains abstract while the real bluebird is in reality, Alain (an impostor who at first wants to live on their account). 
Contrary to the conception of happiness as a state of lasting joy and/or pleasure, it becomes connected here to the satisfaction of all desires and to an infinite fragmentation: happiness is made of successive moments of well being put together. Alain realizes that happiness occurs in brief moments but he knows that these moments are ephemeral because he has understood that death as well as society will interrupt them. Happiness in this novel arises from a perfect coincidence between what we are and what we do. Happiness comes from these privileged moments where the individual is no longer fooled by futile illusions but tries to become oneself ignoring the demands of society.

The figures of old age emerging from this literary production let appear new strategies of appropriation of old age to a new era of writing.

\section{Happiness in the Era of Emptiness}

In the hypermodern society, it is hard to be happy. According to Giles Lipovetsky: "the hypermodern culture is characterized by the weakening of the regulatory power of collective institutions" (Lipovetsky, 2004, pp. 81-82). He refers to the individual who is becoming more open and mobile and socially independent. This is what many contemporary authors are struggling to express in their work in their own way. Michel Houellebecq talks about the decadence of modern society: "Lately, we move towards two dimensions: the erotic attraction and money. People's Happiness and misery derive from them" (Houellebecq, 1998, p. 42).

Is it possible to consider happiness or at least what could possibility lead to happiness according to Houellebecq? While the heroes of his texts are mostly burdened characters, it would seem odd to consider any notion of happiness. In the stories which deal especially with provocative themes-like isolation, frustration as a constitutive principle of the characters, the endless struggle for the satisfaction of physical desires and materials, in a world where the liberal logic organizes everything, from work to sexuality—little room is left for happiness. Indeed, how can we imagine for a moment a quest for happiness in stories where sexual consumption is compared and even equated with financial consumption, where most of the characters are depressed? However, it is possible to consider a pursuit of happiness, based primarily on the doctrine of the spiritual master Houellebecq, namely, Schopenhauer cited several times, who has strongly marked his stories.

In the 19th century, Schopenhauer (1788-1860) developed new perspectives drawing a pessimistic concept of life published in 1818 in The World as Will and Representation (Schopenhauer, 2011). Schopenhauer's doctrine presents Man as condemned to suffering since he is tragically guided by Will which must be refuted if he wants to stop being unhappy. Through the various stages of suffering man can get to the point where the will is completely abolished, and thus, attain Nirvana (a well known influence of Buddhism on the German philosopher). In other words, it is first necessary to experience pain in order to reach the stage of Will redemption and finally, its denial. There is only one road that leads to salvation:

that the will shall manifest itself unrestrictedly, in order that in this individual manifestation it may come to apprehend its own nature. Only as the result of this knowledge can the will transcend itself, and thereby end the suffering which is inseparable from its manifestation. (Schopenhauer, 2011, p. 518)

Only then does it become possible to conceive happiness that would be the end of the process of suffering. This idea is also expressed in the texts of Houellebecq. In Whatever (Houellebecq, 1998), Tisserand suffers from sexual frustration, and competition between males is cruel. The same features recur in Platform (Houellebecq, 2004) with sex tourism expected to bring a cynical solution to the Europeans; in The Elementary 
Particles (Houellebecq, 2001), sexual freedom is meant to solve the problems, although in the end, it only makes them worse: Bruno ends up in an asylum; however, his brother Michel, a scientist, seems to bring a solution (of organic order) for all the human woes (by the removal of sexual reproduction and its replacement by cloning) and in The Possibility of an Island (Houellebecq, 2007), this solution is even strengthened. Neo-humans live in a world that is neither Eden nor misery; realization of the Buddhist Nirvana is a homeostatic world where the principles of pleasure as well as that of desire and reproduction have been completely abolished.

Schopenhauer insists on the fact that sexuality represents the expression of the will to live and thus, when abolishing it, it becomes possible to achieve a kind of serenity. We find the same idea in Atomized where the central character Michel Djerzinsky has engaged in science feeling a much greater satisfaction than the one felt in sexual intercourse. In The Possibility of an Island Daniel1's clones-Daniel 24 and Daniel 25-who know nothing about sexuality have reached the neo-human stage where they live quietly. At this stage, satisfaction is annihilated because it is originally only a deliverance from pain. True happiness is not happiness if preceded by suffering and desire, but a state of knowledge and pure objectivity, which more or less characterizes the neo-humans in The Possibility of an Island.

Le Clézio, for his part, closely associates happiness to children. In modern society, only the innocent child can be happy. However, in other non-European civilizations, it is possible to achieve a kind of peaceful state. For instance, one may find joy associated with the freedom of the nomads in the desert (Desert, 2011). The desert, empty of any human presence, is a space of lack and deprivation, wandering, lack and silence. While modern societies are spaces of exclusion, enslavement and injustice, nomadic or Indian societies offer freedom. Le Clézio, through the writing of journeys, highlights the fact that freedom and wandering are the sources of human happiness.

In his recognition of forgotten civilizations, Le Clézio has certainly detected a place on earth where it is possible to do away with the institution of Western culture, entirely based on relations of domination and power. Le Clézio re-establishes innocence, peace, and happiness of the first men who lived in harmony with the world of silence and nature.

Le Clézio's characters make initiatory journeys, they are lonely and evolve generally towards the search for individual serenity and deepening of a personal quest for happiness. That can only be achieved in solitude, an indispensable condition for those who want to detach from superficiality of an insensitive world. In Le Clézio's novels Eastern civilization can only lead to an illusion of happiness, while the positive loneliness, that of the natural man, is supposed to lead after an initiation quest, to a journey towards a possible hope, or a reward after a great effort.

\section{Conclusion}

If we wish to sum up and assemble the elements of this study we should emphasize that:

- in the early twentieth century, an approach of happiness appears in the novels that it is first "to be rather than to do".

- Under the influence of nihilism, a thought developed in the thirties, reflecting the fact that God has replaced the infinite appetites and unlimited desire.

- The interest of happiness persists in postmodernism where the whole mass culture is on trial in the novel.

- That marital happiness is still the subject of the novel today, but this time it is more in order to put the 
subject in derision.

- A group of authors called the "positive minimalists" postulate a notion of happiness based on a new way of life - and on writing — built around the everyday.

- The figures of old characters, emerging from the French novel express new strategies of appropriation of old age and a pursuit of happiness.

- True happiness is not anymore a happiness preceded by suffering and desire, but a state of knowledge and pure objectivity.

Happiness continues to appear in the French novel despite the existentialist approach and the Holocaust, after which happiness is only mentioned in the texts. The reflection of happiness increases within postmodernism where the whole mass culture is on trial.

But the writing of happiness today seems to proceed differently and expresses a contemporary specificity, revealing the singular posture of our time. The French novel development in the second part of the twentieth century shows a phenomenon of rewriting the happiness theme. Man is more than ever faced with a world where unity, coherence and meaning are questioned and so is the concept of happiness. At a time when many paradoxes accompany the pursuit of well-being, it seems to have shifted from being a universal concept to an intimate, personal one.

It appeared that in today's world, dominated by technology, excessive productivity and effectiveness, in an era where "consumerist vision is characterized by the centrality of welfare aims and search of a better life", happiness or at least the pursuit of happiness proved to be present and significant in the contemporary novel.

The writing of happiness has moved without doubt from a universal concept to an intimate, personal one. At the same time, these narratives cultivate a range of styles (irony), performances (fantastic incursions, storytelling), tones (realistic, unreal), voices (poetic, prosaic, scientific) which all help to create a favourable atmosphere for the theme of happiness.

\section{References}

Alain, E. C. (1973). On happiness. New York: Ungar.

Baudrillard, J. (1983). La Société de consommation, ses mythes, ses structures (The consumer society: Myth and structure). London: Sage Publication Ltd.

Bertrand, R. (1930). The conquest of happiness. Retrieved from http://russell-j.com/beginner/COH-TEXT.HTM

Boyer-Weinmann, M. (2011). Bonheurs sénescents: le gai savoir du vieillir dans les récits de Régine Detambel (Old happiness: Happy knowledge in RégineDetambel's stories). L'Ecriture du bonheur dans le roman contemporain (The writing of happiness in the contemporary novels) (pp. 165-176). Textes réunis et édité par Ruth Amar Cambridge: CSP.

Bruckner, P. (2003). Bitter moon. Berlin: Aufbau Tb.

Bruckner, P. (2011). Perpetual euphoria: On the duty to be happy. Princeton: Princeton University Press.

Camus, A. (1955). The myth of Sisyphus, and other essays. New York: A. Knopf.

Camus, A. (1959). "Gros plan" Television Program.

Camus, A. (1963). The Fall. London: Penguin Books.

Camus, A. (1965). The outsider, Harmondsworth Middx. London: Penguin Books.

Camus, A. (1967). Betwixt and between, lyrical and critical essays. USA: A Vintage Book.

Camus, A. (1967). Nuptials: Lyrical and critical essays. USA: A Vintage book.

Camus, A. (1967). The plague. London: Hutchinson Educational.

Certeau, M. D. (1988). The Practice of Everyday Life, 1 / Arts to do the first part, 'A Very Ordinary Culture. Berkeley: University of California Press.

Cespedes, F., Baritaud, B., \& Anglard, V. (1991). L'idée de bonheur chez Stendhal, Gide, Giono (The idea of happiness in Stendhal, Gide, Giono's work). Paris: Pierre Bordas et Fils. 
Chardonne, J. (2000). Les Destinées sentimentales (Sentimental destinies). Paris: Broché.

Comte-Sponville, A. (2003). Le Bonheur Désespérément (Happiness desperately). Broché: Paris.

Gazier, M. (1999). Le Merle bleu (The Bluebird). Paris: Seuil.

Gazier, M. (2001). Le Fil de soie (The Silk Thread). Paris: Seuil.

Gide, A. (1935). Les nouvelles Nourritures, livre premier (The new earthly food). Paris: Gallimard.

Holder, E. (2002). Mademoiselle Chambon. Paris: Flammarion.

Houellebecq, M. (1998). Intervention. Paris: Flammarion.

Houellebecq, M. (1998). Whatever. UK: Serpent's Tail.

Houellebecq, M. (2001). The elementary particles. New York: Vintage.

Houellebecq, M. (2004). Platform. New York: Vintage International.

Houellebecq, M. (2007). The possibility of an island. New York: A. Knopf.

Le Clézio, J. M. G. (2011). Desert. London: Atlantic Books.

Lipovetsky, G. (2004). Hypermodern Times. Paris: Grasset.

Montherlant, H. D. (1986). The girls, a tetralogy of novels in two volumes. London: Weidenfeld \& Nicolson.

Pawin, R. (2011). Les romans dédiés au bonheur (France, 1960-1980) (The novels dedicated to happiness (France, 1960-1980)). In L'Ecriture du bonheur dans le roman contemporain (The Writing of Happiness in the Contemporary Novels) (pp. 165-176). Cambridge: CSP.

Pawin, R. (2013). Histoire du bonheur en France depuis 1945 (History of happiness in France since 1945) (pp. 19-32). Paris: Laffont.

Rochefort, C. (1966). Une Rose pour Morrison (A Rose for Morrison). Paris: Broché.

Rochefort, C. (1978). Les Stances à Sophie (Sophie's Stances). New York: French \& European Pubns.

Sartre, J. P. (1946). Existentialism is a humanism. Retrieved from http://cla.calpoly.edu/ lcall/307/sartre.pdf

Schopenhauer, A. (2011). The world as will and idea. Retrieved from https://www.gutenberg.org/files/38427/38427-pdf.pdf

Visage, B. (1998). Les Moins-que-rien (The less-than-nothing). In La Nouvelle Revue Française (pp. 3-10). 